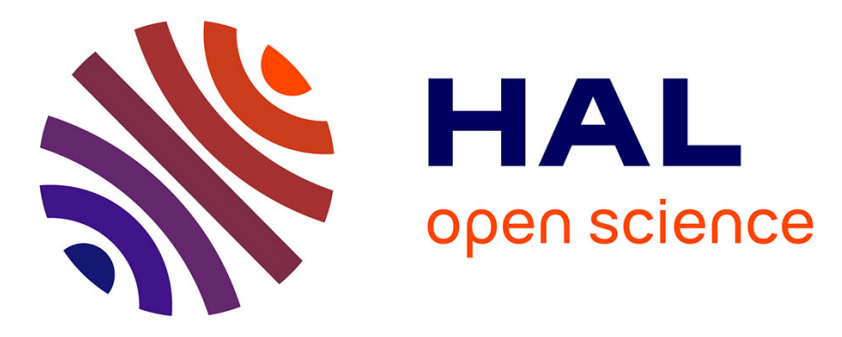

\title{
Soil-Root Interactions in Mixed Plant Systems
}

Samuel G.K. Adiku, Laj R. Ahuja, Harry Ozier Lafontaine, G.H. Dunn, L.

Garcia

\section{To cite this version:}

Samuel G.K. Adiku, Laj R. Ahuja, Harry Ozier Lafontaine, G.H. Dunn, L. Garcia. Soil-Root Interactions in Mixed Plant Systems. Enhancing Understanding and Quantification of Soil-Root Growth Interactions, 4, American Society of Agronomy; Crop Science Society of America; Soil Science Society of America, 324 p., 2013, Advances in Agricultural Systems Modeling, 978-0-89118-338-9. 10.2134/advagricsystmodel4.c11 . hal-02807793

\section{HAL Id: hal-02807793 https://hal.inrae.fr/hal-02807793}

Submitted on 6 Jun 2020

HAL is a multi-disciplinary open access archive for the deposit and dissemination of scientific research documents, whether they are published or not. The documents may come from teaching and research institutions in France or abroad, or from public or private research centers.
L'archive ouverte pluridisciplinaire HAL, est destinée au dépôt et à la diffusion de documents scientifiques de niveau recherche, publiés ou non, émanant des établissements d'enseignement et de recherche français ou étrangers, des laboratoires publics ou privés. 
Advances in Agricultural Systems Modeling

Transdisciplinary Research, Synthesis, and Applications

Laj Ahuja, Series Editor

\section{Volume 4 \\ Enhancing Understanding and Quantification of Soil-Root Growth Interactions}

Dennis Timlin and Laj R. Ahuja, Editors

Book and Multimedia Publishing Committee April Ulery, Chair Warren Dick, ASA Editor-in-Chief E. Charles Brummer, CSSA Editor-in-Chief Andrew Sharpley, SSSA Editor-in-Chief Mary Savin, ASA Representative Mike Casler, CSSA Representative David Clay, SSSA Representative Managing Editor: Lisa Al-Amoodi 


\section{Copyright $\odot 2013$ by American Society of Agronomy, Inc. Crop Science Society of America, Inc. Soil Science Society of America, Inc.}

ALL RIGHTS RESERVED. No part of this publication may be reproduced or transmitted in any form or by any means, electronic or mechanical, including photocopying, recording, or any information storage and retrieval system, without permission in writing from the publisher.

The views expressed in this publication represent those of the individual Editors and Authors. These views do not necessarily reflect endorsement by the Publisher(s). In addition, trade names are sometimes mentioned in this publication. No endorsement of these products by the Publisher(s) is intended, nor is any criticism implied of similar products not mentioned.

American Society of Agronomy, Inc.

Crop Science Society of America, Inc.

Soil Science Society of America, Inc.

5585 Guilford Road, Madison, WI 53711-5801 USA

agronomy.org | soils.org | crops.org

dl.sciencesocieties.org

societystore.org

ISBN: 978-0-89118-338-9 (print)

ISBN: 978-0-89118-339-6 (electronic)

doi:10.2134/advagricsystmodel4

Library of Congress Control Number: 2013936612

Advances in Agricultural Systems Modeling

ISSN: 2163-2790 (online)

ISSN: 2163-2774 (print)

Cover design: Patricia Scullion

Cover photo: Sunflower seedling with roots. Jason Young, USDA-ARS, Water Management Research Unit, Fort Collins, CO. 
Foreword

vii

Preface

ix

Contributors

$\mathrm{xi}$

Chapter 1

1

Rhizosphere Engineering by Plants: Quantifying Soil-Root Interactions

Peter J. Gregory, A. Glyn Bengough, Timothy S. George, and Paul D. Hallett

Chapter 2

Effect of Soil Attributes on Root Growth and Distribution in Some Common

Crops: A Synthesis of Knowledge and Future Needs

J. Benjamin

Chapter 3

45

Root Growth and Distribution in Relation to Different Water Levels

Xiying Zhang and Chunsheng Hu

Chapter 4

67

Nitrogen Management Effects on Root Systems: A Synthesis and Future Needs

Juan M. Herrera and Peter Stamp

Chapter 5

93

Characterization of the Root Length Density Distribution of Wheat Using

a Generalized Function

Qiang Zuo, Renduo Zhang, and Jianchu Shi

Chapter 6

Differences in One-, Two-, and Three-Dimensional Modeling of Root Growth for Estimating Water and Nutrient Uptake and the Carbon Cycle

L. Wu and I. J. Bingham

Chapter 7

Modeling Lolium perenne L. Roots in the Presence of Empirical Black Holes

Richard W. Zobel

Chapter 8

Root Effects on Soil Properties and Processes: Synthesis and Future Research Needs

S.D. Logsdon

Chapter 9

Reinforcement of Soil by Fibrous Roots

Kenneth W. Loades, A. Glyn Bengough, M. Fraser Bransby, and Paul D. Hallett 
Simulating Root Development and Soil Resource Acquisition in Dynamic Models of Crop-Weed Competition

Andres G. Berger, Andrew J. McDonald, and Susan J. Riha

Chapter 11

Soil-Root Interactions in Mixed Plant Systems

S.G.K. Adiku, L.R. Ahuja, H. Ozier-Lafontaine, G.H. Dunn, and L. Garcia

Chapter 12

Modeling Resource Interactions Under Multiple Edaphic Stresses

Annette Dathe, Johannes A. Postma, and Jonathan P. Lynch

Chapter 13

Simulation of Soil-Root Growth Interactions and Associated Processes:

Synthesis and Summary

Dennis Timlin and Laj Ahuja

Index

About the Series 
Scientists cannot easily visualize or understand plant root growth and function in the soil. Yet, $50 \%$ or more of most plant growth occurs below the soil surface and interacts with the rhizosphere. Roots are dynamic organs that respond to physical, chemical, and hydrologic properties of the soil, as well as stimuli from aboveground plant parts. An understanding of the rhizosphere allows us to better understand plant growth responses to the environment as well as resource conservation and climate change. This interdisciplinary book describes methods, modeling efforts, and future needs so that the root systems and interactions with the soil can be better understood. This information is critical to advance efforts to improve water use and nutrient efficiencies, reduce pest impacts, and increase carbon sequestration. Contributors to this volume are respected international experts representing a wide array of scientific disciplines, including soil scientists, plant physiologists, and microbiologists. We thank the editors Drs. Timlin and Ahuja and all authors for their significant contributions to our understanding of soil-root growth interactions, the implications of these interactions, and their thoughts about future research directions.

Sharon Clay, 2013 ASA President

Mark Brick, 2013 CSSA President

David L. Lindbo, 2013 SSSA President 
Dynamic root growth in response to soil conditions is important to the most efficient use of soil water and nutrient resources. Thus, a better understanding of the interactions of soil properties and processes with plant root growth and function is of interest to many disciplines, within soil science and beyond. Further research is urgently needed in this area to gain better understanding and quantification to find solutions to society's growing problems in the conservation of water and soil resources and their quality. Agriculture must maximize the use of increasingly limited water available for food production, enhancing the use of soil nutrient resources. This is especially critical to nations who cannot afford the costly fertilizers and to the world where soil carbon storage can be utilized to reduce climate change effects of elevated $\mathrm{CO}_{2}$. Research progress in the area of soil-root growth interactions, however, has been slow due to the relative inaccessibility of roots in their natural environment and the fact that root research cuts across the boundaries of soil science, ecology, crop science, and plant physiology, among others. As is often the case in research, many scientists often work in isolation of other disciplines due to limited time and resources or the need to concentrate on a limited scope to a particular problem. This can lead to the neglect of, often very important, interactions on the boundaries of disciplines. An important component that ties together the many diverse processes in soils is the rhizosphere. Unfortunately this critical component is left out of many projects. The subject for the book volume is a transdisciplinary area of critical knowledge gaps. Therefore, the overall motivation for this book is to bring together scientists from different disciplines, worldwide, together to encourage synthesis of transdisciplinary knowledge and further research and developments in the area of root-soil interactions.

The plant root system has been described as the "hidden half" (Plant roots: The hidden half, Yoav Waisel, Amram Esthel, and Uzi Kafkafi, editors, Marcel Dekker, New York). This term implies both the unknown and difficult to measure nature of the root system, as well as its importance as making up at least half the plant system. Because of difficulties in measuring plant root systems and related processes, there is a dearth of quantifiable data that would be useful to plant modelers to develop equations and algorithms of root growth, and water and nutrient uptake under a range of soil conditions. The objective of this book is to document recent advances in understanding, synthesis, and quantification of the effects of soil attributes, the rhizosphere, and management on root growth and architecture, and vice versa, in relation to uptake of soil water and nutrients and soil carbon sequestration. This knowledge can then used to improve models of these processes.

Based on a review of the subject matter by the editors, some of the specific areas of knowledge gaps needing better understanding and quantification for system models are listed below.

1. Rhizosphere role in soil-root interactions

2. Effect of soil properties and the rhizosphere on root growth, root length density, diameter and architecture; total vs. active functional roots 
3. Impact of root growth on soil hydraulic properties over time and interaction with microfauna in the soil

4. Quantification of vertical and lateral root growth responses to water and nutrient availability and soil impedance changes with matric potential

5. Differences in dynamic response of root growth and architecture in different crops under unstressed and stressed conditions: modeling and reality

6. Interacting root and soil parameters that affect water and nutrient uptake: root length density (RLD) distribution, root and shoot hydraulic properties, soil water potential and conductivity, root contact, and soil fauna

7. Contribution of root growth and architecture and the rhizosphere to carbon sequestration under unstressed and stressed conditions

Contributions for this volume listed under the next section have been selected around these areas and come from a compilation of papers from a symposium titled "Enhancing Understanding and Quantification of SoilRoot Growth Interactions" at the 2009 International Annual Meetings of the American Society of Agronomy, Crop Science Society of America, and Soil Science Society of America.

We hope this volume will also encourage further research and developments in the area of root-soil interactions and the rhizosphere through coordination and collaborations worldwide.

Dennis Timlin and Laj Ahuja, Editors 
Adiku, S.G.K. Dep. of Civil and Environmental Engineering, Engineering Building, Colorado State Univ., Fort Collins, CO 80523 (s_adiku@hotmail.com), presently at Dep. of Soil Science, Univ. of Ghana, P.O. Box LG 245, Legon, Accra, Ghana (s_adiku@ug.edu.gh)

Ahuja, L.R.

USDA-ARS, Agricultural Systems Research Unit, 2150 Building D, Center Ave., Fort Collins, CO 80526 (laj.ahuja@ars.usda.gov)

Bengough, A.G. The James Hutton Institute, Invergowrie, Dundee DD2 5DA, Scotland UK (glyn. bengough@hutton.ac.uk)

Benjamin, J. Central Great Plains Research Station, USDA-ARS, 40335 Co. Rd. GG, Akron, CO 80720 (joseph.benjamin@ars.usda.gov)

Berger, A.G. Dep. of Earth and Atmospheric Sciences, Cornell Univ., Ithaca, NY 14853 (aberger@inia.org.uy); presently at INIA La Estanzuela, Ruta 50 km 11, Colonia 70000, Uruguay (aberger@inia.org.uy)

Bingham, I.J. Crop and Soil Systems Research, SRUC, King's Buildings, West Mains Road, Edinburgh EH9 3JG, UK (ian.bingham@sruc.ac.uk)

Bransby, M.F. Division of Civil Engineering, Univ. of Dundee, Dundee, DD1 4HR, UK (fraser. bransby@gmail.com)

Dathe, A.

Dep. of Plant Science, Pennsylvania State Univ., 102 Tyson, University Park, PA 16802 (annette.dathe@ars.usda.gov), presently at Wye Research and Education Center, Univ. of Maryland, Queenstown, MD 21658

Dunn, G.H.

USDA-ARS, Agricultural Systems Research Unit, 2150 Building D, Center Ave, Fort Collins, CO 80526 (gale.dunn@ars.usda.gov)

Garcia, L.

George, T.S.

Dep. of Civil and Environmental Engineering, Engineering Building, Colorado State Univ., Fort Collins, CO 80523 (gar-cia@engr.colostate.edu)

The James Hutton Institute, Invergowrie, Dundee DD2 5DA, Scotland UK (tim. george@hutton.ac.uk)

Gregory, P.J. The James Hutton Institute, Invergowrie, Dundee DD2 5DA, Scotland UK (peter.gregory@emr.ac.uk); presently at Centre for Food Security, School of Agriculture, Policy and Development, Univ. of Reading, Reading RG6 6AR, UK; East Malling Research, New Road, East Malling, Kent ME19 6BJ, UK (peter. gregory@ems.ac.uk)

Hallett, P.D. The James Hutton Institute, Invergowrie, Dundee DD2 5DA, Scotland UK (paul. hallett@hutton.ac.uk)

Herrera, J.M. Instituto de Investigaciones en Biociencias Agrícolas y Ambientales (INBA) Facultad de Agronomía, Univ. de Buenos Aires, Ave. San Martín 4453, Buenos Aires, C1447DSE, Argentina (herreraj@agro.uba.ar)

$\mathrm{Hu}, \mathrm{C}$.

Center for Agricultural Resources Research, Institute of Genetics and Developmental Biology, Chinese Academy of Sciences, 286 Huaizhong Road, Shijiazhuang, China, 050021 (cshu@sjziam.ac.cn)

Loades, K.W. The James Hutton Institute, Invergowrie, Dundee, DD2 5DA, UK (kenneth. loades@hutton.ac.uk)

Logsdon, S.D. National Laboratory for Agriculture and the Environment, USDA-ARS, 2110 University Blvd., Ames, IA 50011 (sally.logsdon@ars.usda.gov)

Lynch, J.P.

Dep. of Plant Science, Pennsylvania State Univ., 102 Tyson, University Park, PA 16802 (jpl4@psu.edu) 
McDonald, A.J. Dep. of Earth and Atmospheric Sciences, Cornell Univ., Ithaca, NY 14853, presently at CIMMYT, Singha Durbar Plaza Marg Bhadrakali, Kathmandu, Nepal (a.mcdonald@cgiar.org)

Ozier-Lafontaine, H. INRA, Unité AgroPédoclimatique de la Zone Caraïbe, 97170 Petit Bourg, Guadeloupe, France (harry.ozier-lafontaine@antilles.inra.fr)

Postma, J.A. Dep. of Plant Science, Pennsylvania State Univ., 102 Tyson, University Park, PA 16802 (j.postma@fz-juelich.de) presently at Forschungszentrum Jülich, IBG2: Plant Sciences, Room 015, Wilhelm-Johnen-Straße, 52425 Jülich, Germany

Riha, S.J.

Dep. of Earth and Atmospheric Sciences, Cornell Univ., 1110 Bradfield Hall, Ithaca, NY 14853 (sjr4@cornell.edu)

Shi, J. Dep. of Soil and Water Sciences, College of Resources and Environment, China Agricultural Univ., and Key Laboratory of Plant-Soil Interactions, Ministry of Education, Beijing 100193, China

Stamp, P. Univ. of Zurich, Inst.f.Pflanzenwissenschaften, ETH Universitatstr. 2, Zurich, 8092, Switzerland (peter.stamp@ipw.agrl.ethz.ch)

Timlin, D. USDA-ARS, USDA-ARS-CSGCL, BIdg. 001, Rm. 342, BARC-West, 10300 Baltimore Ave., Beltsville, MD 20705-2350 (Dennis.Timlin@ars.usda.gov)

$\mathrm{Wu}, \mathrm{L}$.

Sustainable Soils and Grassland Systems, Rothamsted Research, North Wyke, Okehampton, EX20 2SB, UK (lianhai.wu@rothamsted.ac.uk)

Zhang, R. School of Environmental Science and Engineering, Sun Yat-Sen (Zhongshan) Univ., Guangzhou 510275, China (zhangrd@mail.sysu.edu.cn)

Zhang, X. Center for Agricultural Resources Research, Institute of Genetics and Developmental Biology, Chinese Academy of Sciences, 286 Huaizhong Road, Shijiazhuang, China, 050021 (xyzhang@sjziam.ac.cn)

Zobel, R.W. Plant Science Research, USDA-ARS, 3127 Ligon St., Box 7631, North Carolina State Univ., Raleigh, NC 27695-7631 (rich.zobel@ars.usda.gov)

Zuo, Q. Dep. of Soil and Water Sciences, College of Resources and Environment, China Agricultural Univ., and Key Laboratory of Plant-Soil Interactions, Ministry of Education, Beijing 100193, China (qiangzuo@cau.edu.cn) 